Journal of History Culture and Art Research (ISSN: 2147-0626)

Tarih Kültür ve Sanat Araştırmaları Dergisi

Revue des Recherches en Histoire Culture et Art

مجلة البحوث التاريخية و الثقافية و الفنية
Vol. 7, No. 3, September 2018

Copyright (C) Karabuk University

http://kutaksam.karabuk.edu.tr

\title{
DOI: 10.7596/taksad.v7i3.1742
}

Citation: Kovaleva, V., Rusetskiy, M., Okorokova, O., Frantsisko, O., \& Antoshkina, A. (2018). Historical and Cultural Aspects of Controlling. Journal of History Culture and Art Research, 7(3), 163-174. doi:http://dx.doi.org/10.7596/taksad.v7i3.1742

\section{Historical and Cultural Aspects of Controlling}

\author{
Valentina Danilovna Kovaleva1, Mikhail Gennad'evich Rusetskiy², \\ Olga Alekseevna Okorokova ${ }^{3}$, Olga Yurievna Frantsisko $^{4}$, Anna Vladimirovna Antoshkina5
}

\begin{abstract}
The article reveals the essence of the notion "controlling" and investigates historical stages in the development of controlling. The characteristic features of each stage of evolution and their interrelation are presented and the effectiveness of controlling toolkit in improving the system of organizationaleconomic management is justified. The main provisions regarding controlling models are revealed and generalized; scientific schools of controlling and their differences are defined and major subsystems of controlling are presented. The main aspects reflecting the essence of the notion "culture" are studied; the role of culture in modern society and in the system of organizational-economic management is determined. Main definitions of the notion "culture", which are most appropriate for characterizing the subsystem of operational controlling, are analyzed. The key aspects of organizational culture characterizing operational controlling as a controlling subsystem are identified; internal and external factors that affect the formation of organizational culture and its changes are defined. Specific features of national culture and their influence on corporate culture of an economic entity are disclosed; characteristics of corporate culture that are taken into account in the process of preparing management decisions are reflected. The development prospects of organizational culture that are based on modern controlling conceptions are considered contributing to further improvement of economic entity's organizational-economic management and to increasing effectiveness in management decisions.
\end{abstract}

Keywords: Culture, Corporate culture, Organizational culture, History, Controlling, the system of organizational-economic management, Conception, Economic entity, Management.

\footnotetext{
${ }^{1}$ Stavropol Institute of Cooperation (Branch) Belgorod University of Cooperation, Economics and Law 36, Goleneva Street, Stavropol, Russia, 355000. E-mail: kvd_stavr@mail.ru

2 North Caucasus Federal University (NCFU) 1, Pushkina Street, Stavropol, Russia, 355009. E-mail: rusetskiym@yandex.ru

${ }^{3}$ Kuban State Agrarian University named after I.T. Trubilin (Kuban SAU) 13, Kalinina Street, Krasnodar, Russia, 350044. E-mail: okorokovaoa1986@mail.ru

${ }^{4}$ Kuban State Agrarian University named after I.T. Trubilin (Kuban SAU) 13, Kalinina Street, Krasnodar, Russia, 350044. E-mail: fricsoolga@mail.ru

${ }^{5}$ Kuban State Technological University (KubSTU) 2, Moskovskaya Street, Krasnodar, Russia, 350072. E-mail: annaant@yandex.ru
} 


\section{Introduction}

The notion "controlling" is characterized by the multifaceted toolkit that is used in organizational-economic management of an economic entity. It is a complex system, the modeling of which is based on various conceptions complementing each other [1]. The following models that reflect the essence of these conceptions are mostly wide-spread:

- $\quad$ the financial-economic model, within which an economic entity is considered as a system that consumes resources of particular value and manufactures products that have certain market value. The effectiveness of the system is assessed by the correlation between profits obtained from selling products and the cost of resources used;

- $\quad$ the process model defining an economic entity as a set of processes. Information, for example, can be the result of a process and a number of errors related to the volume of the processed information can be an effectiveness indicator;

- $\quad$ the marketing model characterizing an economic entity's position in the market;
- $\quad$ the model of an economic entity as a cash flow generator;
- $\quad$ the model of an economic entity as an employer characterizing its position in the labor market;
- $\quad$ the model of intellectual capital determining an economic entity as a system of knowledge management;

- $\quad$ the model of corporate culture characterizing an economic entity's value system.

Each model sets a certain projection, in which the economic entity's activities are considered and assessed. It is evident that a complete business picture can be obtained by means of a wide range of projections, the choice of which depends on management approaches. However, present-day managers do not always pay enough attention to such aspects as corporate culture and intellectual capital in the mistaken belief that the latter are not included into the system of organizational-economic management.

At the same time culture is a continuous process of human's self-reproduction that is carried out through material and spiritual activities. It is the human who is the main culture subject and object; his knowledge makes up intellectual capital of an economic entity. Due to this fact any social organizations can be culture subjects and objects (organizational culture, professional labor culture).

Organizational culture is a specific, inherent only in the given organization, self-sufficient system of links, interactions, relations, elements necessary for its functioning [2]. It is not only an original combination of values, relations, norms, habits, traditions, forms of behavior and rituals but also all organization's habitat and self-realization and a style of relations and behavior inherent in it. Each economic entity possesses its own individual culture that influences its development efficiency.

At the turn of the $21^{\text {st }}$ century organizational culture is becoming more and more powerful factor influencing the effectiveness of economic activity. In this regard, management's activity must be oriented towards the formation and purposeful change of the culture vector in the system of organizationaleconomic management basing on modern technologies. Under the conditions of increased uncertainty of market economy and due to strengthening of competition aggressiveness it is necessary for economic entities' management to pay more attention to introducing modern technologies of business management. A principal role in this case is given to controlling. Investigating historical stages in the evolution of controlling contributes to the implementation of its subsystems in organizational-economic management and enables to improve corporate culture. 


\section{Methodology}

The methodological basis of the study is the dialectical approach to the cognition of phenomena and patterns of the development of controlling, which includes organizational culture as a subsystem to improve a system of economic activity management. The research is based on the theory and methodology related in the fundamental works of Russian and foreign scientists on the problems of the formation and development of controlling and organizational culture as its subsystem [3].

In the scientific world the notion "culture" is analyzed in greater detail in order to work out a correct definition. Western scientists were the first to carry out research in this regard. According to American anthropologists, the first definition of culture was given by an English ethnographer Edward Tylor (18321917). "Culture is that complex whole which includes knowledge, belief, art, morals, law, custom, and any other capabilities and habits acquired by man as a member of society" [4].

The use of theoretic approaches and the concept of economic integration combined with the principles of social and cause-and-effect approaches enabled to investigate the main stages of the development of controlling and organizational culture of an economic entity as its subsystem at a sufficiently high scientific level.

In the work the methods of system analysis were implemented that included a complex of general scientific methods (system, complexity, dialectics, induction and deduction, analysis and synthesis), the methods of morphological analysis (management by objectives) and logical modeling.

\section{Results}

The main aspects that reflect the essence of the notion "culture" are studied; the role of culture in the system of organizational-economic management of an economic entity is defined. It is established that organizational culture as a management object can change fast enough which makes it a subsystem of operational controlling. However, organizational culture cannot be formed without taking into consideration national culture. In this regard, the peculiarities of national culture should be taken into account when forming and deliberately changing a vector of organizational culture as a subsystem of operational controlling. Table 1 presents a combination of indicators determining the cultural characteristics of various peoples (developed by a Dutch social psychologist, Geert (Gerard Hendrik) Hofstede, on the basis of the researches conducted in the 1960-1970s) [5, 6].

Table 1. Culture dimension scores for ten countries

\begin{tabular}{|l|l|l|l|l|l|}
\hline Country & $\begin{array}{l}\text { Power } \\
\text { Distance }\end{array}$ & Individualism & Masculinity & $\begin{array}{l}\text { Uncertainty } \\
\text { Avoidance }\end{array}$ & $\begin{array}{l}\text { Long-term } \\
\text { Orientation }\end{array}$ \\
\hline USA & $40(\mathrm{~L})$ & $91(\mathrm{H})$ & $62(\mathrm{H})$ & $46(\mathrm{~L})$ & $29(\mathrm{~L})$ \\
\hline Germany & $35(\mathrm{~L})$ & $67(\mathrm{H})$ & $66(\mathrm{H})$ & $65(\mathrm{M})$ & $31(\mathrm{~L})$ \\
\hline Japan & $54(\mathrm{M})$ & $46(\mathrm{M})$ & $95(\mathrm{H})$ & $92(\mathrm{H})$ & $80(\mathrm{H})$ \\
\hline France & $68(\mathrm{H})$ & $71(\mathrm{H})$ & $43(\mathrm{M})$ & $86(\mathrm{H})$ & $30(\mathrm{~L})$ \\
\hline Holland & $38(\mathrm{~L})$ & $80(\mathrm{H})$ & $14(\mathrm{~L})$ & $53(\mathrm{M})$ & $44(\mathrm{M})$ \\
\hline Hong Kong & $68(\mathrm{H})$ & $25(\mathrm{~L})$ & $57(\mathrm{H})$ & $29(\mathrm{~L})$ & $96(\mathrm{H})$ \\
\hline
\end{tabular}




\begin{tabular}{|l|l|l|l|l|l|}
\hline Indonesia & $78(\mathrm{H})$ & $14(\mathrm{~L})$ & $46(\mathrm{M})$ & $48(\mathrm{~L})$ & $25(\mathrm{~L})$ \\
\hline West Africa & $77(\mathrm{H})$ & $20(\mathrm{~L})$ & $46(\mathrm{M})$ & $54(\mathrm{M})$ & $16(\mathrm{~L})$ \\
\hline Russia & $95(\mathrm{H})$ & $50(\mathrm{M})$ & $40(\mathrm{~L})$ & $90(\mathrm{H})$ & $10(\mathrm{~L})$ \\
\hline China & $80(\mathrm{H})$ & $20(\mathrm{~L})$ & $50(\mathrm{M})$ & $60(\mathrm{M})$ & $118(\mathrm{H})$ \\
\hline
\end{tabular}

Note: The figures denote the scores that reflect culture dimensions: $\mathrm{H}-$ high, $\mathrm{M}-$ medium, $\mathrm{L}-$ low.

The first dimension is labeled power distance and it is defined as the degree of inequality among people which the population of a country considers normal or acceptable. The low degree characterizes relative equality in society, whereas the high degree manifests extreme inequality.

The second dimension is individualism. The high degree of this dimension implies that a person being under conditions of free social ties takes full responsibility for himself and his family as well as for his own actions. This very dimension can be called collectivism (low individualism). In collectivist societies a child learns to respect the group to which it belongs, usually the family, race, clan or organization. Group members expect the group to protect them when they are in trouble. In return, they have to remain loyal to their group throughout life. In individualist societies a child learns to think of itself as "I" instead of as part of "we". It is expected that a person will have to stand on his own feet on day and will not get protection from his group; the group will not take responsibility for him. Therefore, an individual should not feel a need to be loyal to the group.

The third dimension also has two opposites: masculinity and femininity that reflect the degree to which people perceive such "tough" values as "assertiveness", "performance", "success and competition", which in almost all societies are associated with the role of men. These values are quite different from "tender" values such as the quality of life, maintaining warm personal relationships, care for the week and solidarity, which in nearly all societies are associated with the role of women. This is the prevalence in society of behavior models inherent to either males or females. The role of women is different from the role of men in all countries but in "tough" societies these differences are bigger than in "tender" ones.

The fourth dimension is uncertainty avoidance. It is defined as the degree to which people in a country prefer structured situations over unstructured ones. Structured situations are those with clear rules of behavior. In countries with strong uncertainty avoidance an opinion prevails that "what is different, is dangerous". In countries with weak uncertainty avoidance there is a feeling that "what is different is curious".

The fifth dimension is the degree of long-term orientation in society members' behavior. Long-term orientation is characterized by the view into the future and is manifested in striving for thrift or saving, persistence in achieving goals. On the short-term side values are oriented towards the past and present and are manifested in respect for tradition and fulfilling social obligations.

The formation and deliberate change of organizational culture with regard to peculiarities of national culture (Table 1) is based on the controlling toolkit. Table 2 presents the main stages in the history of the controlling development in view of two aspects:

- controlling as philosophy and a way of thinking oriented towards the effective use of resources and towards the development of an economic entity in the long term; 
- controlling as an integrated system of informational-analytical and methodological support oriented towards goals achievement in the process of planning, controlling, analyzing and making management decisions in all functional spheres of an economic entity's activity.

Table 2. The main stages in the development of controlling

\begin{tabular}{|c|c|}
\hline Stage & Controlling characteristics \\
\hline $\begin{array}{l}\mathrm{XV} \\
\text { century }\end{array}$ & $\begin{array}{l}\text { An attempt to solve the state management tasks with the use of the controlling ideas was initiated } \\
\text { (in the court of an English king the position of "controller" was established). }\end{array}$ \\
\hline 1778 & $\begin{array}{l}\text { The department "Controller, Auditor, Treasurer and six Commissioners of Accounts" was established; } \\
\text { it aimed at managing the state economy and at controlling the use of funds (USA). }\end{array}$ \\
\hline \multirow[t]{2}{*}{$\begin{array}{l}1880- \\
1892\end{array}$} & $\begin{array}{l}\text { The position of "controller" was established by the companies "Atchison, Topeka and Santa Fe } \\
\text { Railroad" and "General Electric" (USA) }\end{array}$ \\
\hline & $\begin{array}{l}\text { Controllers had to deal with financial economic issues and perform audits. This was due to the } \\
\text { specifics of American corporate legislation that provided only two governing bodies: A General } \\
\text { Meeting of Shareholders and a Board of Directors that required information management. }\end{array}$ \\
\hline $\begin{array}{l}\text { XX } \\
\text { century }\end{array}$ & $\begin{array}{l}\text { Functions of controllers were limited to the registration of information which enabled to make reports } \\
\text { for managers; controllers also dealt with revising the previous facts of economic life (retrospective } \\
\text { orientation) (USA). }\end{array}$ \\
\hline $\begin{array}{l}1929- \\
1933\end{array}$ & $\begin{array}{l}\text { During the Great Depression the global economic crisis drew more attention to the methods and ideas } \\
\text { of controlling with a focus on future activity and not just on the past facts. Accounting and reporting } \\
\text { were transformed from tools of control into a means of overcoming future problems. Since } 1930 \\
\text { controlling has been developing as a management accounting system. A special role in the } \\
\text { development of the controlling system was played by "The Controllers Institute of America", } \\
\text { established in } 1931 \text { (in } 1962 \text { it was renamed to "Financial Executive Institute" (FEI)). This is a } \\
\text { professional organization of US controllers, which conducts a lot of work to systematize the tasks of } \\
\text { controlling. In } 1962 \text { "Financial Executive Institute" (FEI) defined the functions of the controller which } \\
\text { enabled to understand the objectives of controlling and strategies for achieving them, such as } \\
\text { planning, preparing and interpreting reports; assessment (calculations) and counseling; issues of } \\
\text { taxation; reports to state bodies; guarantees of property; macroeconomic research. }\end{array}$ \\
\hline 1934 & "The Controller" journal that dealt with the practical problems of controlling was established (USA). \\
\hline 1944 & $\begin{array}{l}\text { A scientific research institute "Controllership Foundation" (presently "Financial Executives Research } \\
\text { Foundation") that significantly contributed to the development of controlling in the USA was } \\
\text { established. }\end{array}$ \\
\hline \multirow{2}{*}{$\begin{array}{l}1972 \text { to } \\
\text { the } \\
\text { present }\end{array}$} & $\begin{array}{l}\text { An organization IMA ("The Institute of Management Accounting") that deals with the standardization } \\
\text { of management accounting was established. }\end{array}$ \\
\hline & $\begin{array}{l}\text { In the modern American concept controlling, in accordance with regulation } 4 \mathrm{~A} \text { of "Statement of } \\
\text { Management Accounting" (SMA), is one of the areas of responsibility of the accountant (economist), } \\
\text { which, in addition to controlling, includes planning, evaluation, reliable reporting, preparation of } \\
\text { external reporting. In accordance with regulation } 1 \mathrm{~A} \text {, controlling is the provision of the integrity of } \\
\text { financial information relating to the activities of the enterprise and its resources; monitoring and } \\
\text { measuring effectiveness and initiating any corrective actions necessary to return activities to the right } \\
\text { track. }\end{array}$ \\
\hline
\end{tabular}


The analysis of the data presented in Table 2 enabled to conclude that the development of controlling in the USA is exclusively practice-oriented. The Anglo-American school is characterized by the pragmatic approach. The format of management accounting is a priority and controlling is considered as one of responsibilities of management accounting. Controllers or accountants (economists) in management accounting are assistant managers; they do not carry out controlling independently but support managers in planning, monitoring and analysis. At the beginning of the $21^{\text {st }}$ century management accounting also included the components of economic philosophy exploring the ethical aspects of economic actors' activities [7].

In the 1950s with American economic expansion controlling began to spread in many European countries. Further development of controlling was manifested in the dualism of its directions: Anglo-Saxon (American) and European (German). At that time in West Germany a special approach to the application of controlling was being formed, despite the fact that in the middle of the 19th century Thyssen and Krupp companies already had certain elements, which could be attributed to the sphere of controlling.

In the 1950-1970s the economy of West Germany was characterized by high GDP growth and industrial production providing the scientific-technological revolution (STE). This period was due to the formation of the "German model" of economic development. The introduction of a management system by responsibility centers could be considered as a prerequisite for the development of controlling in German companies. The development and implementation of controlling in those decades were directly related to changes in the external environment of companies, significant reorientation of business outlook and actions. There was no concept of management accounting in the theory and practice of managing German companies: the database included production and financial accounting indicators. The term "controlling", which was borrowed from the English language, began to indicate a qualitatively new phenomenon in the management of companies.

Approximately in 1965 in Germany the formation of profit centers in large companies was widespread, which were autonomous in terms of management and accounting. To regulate and manage their activities the use of previous tools did not produce the expected results. The introduction of controlling is largely associated with the name of Albrecht Deyhle. In 1967 Albrecht Deyhle's book, "Controller-Praxis", was published, in which the concept of controlling was viewed as an effective profit management tool [8].

As the administrative doctrine controlling has been used since 1970s, mainly in large corporations in Germany, Austria and Switzerland. From this point forward, the theory of controlling has been seriously developed. The increased demand for controlling services stimulated the emergence of a number of scientific and educational institutions. The Institute of Controllers for Education in the Field of Enterprise Planning and Accounting (Controller-Institut zur Ausbildung und Unternehmensplanung und Rechnungswesen $\mathrm{GmbH}$, Cauting) was the first to emerge. Since 1971 private and public seminars have been held by the Academy of Controllers. In 1989 a special edition of the "Controller" was issued promoting the ideas and philosophy of controlling. Institutionally, the steps taken positively influenced the practical activities of German companies, most of which began to have separate controlling units [9], [10].

In Russia the theoretical ideas of controlling for the first time appeared on the pages of the journal "Schetovodstvo" ("Accounting") (1895) in the works of an Italian accounting professor Giuseppe Rossi, in which a special role was assigned to control as an accounting function. According to G. Rossi, to analyze information on economic activities transforming accounting data to the level of performers is necessary for conducting control. Rossi noted, "It is necessary analyze data in relation to persons who are involved in the economic organism" [11].

Control allows the chief accountant, who knows accumulated accounting records, to be the leading figure for persons who both make management decisions and perform them. As a result, the chief accountant 
fulfills a new advisory function in all management decisions that is "to increase or cut production, change the activities of the enterprise, assign a sales price of goods, increase or decrease the amount of interest, conclude a contract; in all these and other countless cases accountants should express their opinion based on full knowledge of their economy, market conditions, existing laws, etc." [11]. Thus, this function was a manifestation of controlling.

In Russia controlling became of interest at the very beginning of the 1990s in the course of economic transformations. Initially, controlling appeared in banks as a result of intensive development of the banking sector. From 1991 to 1995 controlling was identified with account costs, and in 1996-1997 it was understood as accounting of costs and results. After the financial crisis in 1998 and as a result of the subsequent economic growth, some large industrial enterprises began to form a new type of management. In 1998-1999 controlling began to cover budgeting, planning and cost management. From 2000 to 2010, in the process of restructuring the financial and economic sector, the understanding of controlling as a supplier and interpreter of information for managers, a coordinator of operational activities of an economic entity prevails.

From 2010 to the present, according to S.G. Falco, the understanding of controlling as a service of internal consulting to advise management of economic entities is typical [12]. The task of the controller includes methodological and consulting assistance in creating a system that manifests itself as economic security (timely detection and prevention of hazards, removal of threats, ensuring the achievement of strategic plans of economic entities). The controller as a business partner contributes to the stability of the economic entity's functioning, anticipating and supplementing the manager's actions under the changing conditions of the market economy.

\section{Discussion}

Our opinion that controlling can be viewed as an element of organizational culture does not contradict the concept of L. Likhtarev, who considers controlling as "management philosophy that shapes a management style and the general business culture" [13].

In the mid-1990s, the main provisions of the concept of business process management (BPM) were formed. Currently, there is an active introduction of process management into economic entities, which led to a shift in the emphasis of controlling to business processes and organizational culture. From the standpoint of the process approach, controlling, in our opinion, is a system for regulating and monitoring the implementation of business processes of an economic entity, establishing criteria for key performance indicators of processes, assessing the effectiveness of their implementation aimed at further improvement taking into account strategic goals and organizational culture.

The study of classical and modern scientific theoretical literature on controlling enabled to identify generally accepted conceptual provisions. The concept of controlling is understood as a complex of judgments about its functional delineation, about institutional design and about a necessary toolkit in terms of objectives of an economic entity relevant to controlling as well as a complex of controlling objectives, which are determined by objectives of an economic entity [14]. However, presently, there is no single system for classifying various concepts of controlling. Both foreign and Russian scientific works present theoretical concepts of controlling, which are rather arbitrary and differ in the interpretation of the relationship between management and controlling. Among the multiple concepts three concepts predominantly focus on the accounting system, on information, on the coordination of economic entity's activities. In this regard, the impossibility to clearly differentiate between the proposed concepts leads to their partial intersection. It should be noted that the opinions of the authors on the concepts of controlling are still different, and the discussions that began at the beginning of the $20^{\text {th }}$ century continue at present. 
We believe that the formation of the theoretical basis of controlling must be linked with the emergence of organizational management concepts, which was developed by Frederick Winslow Taylor at the beginning of the industrial era. In his work "The Principles of Scientific Management", published in 1911, Taylor focused on the need for corporate labor to eliminate inefficient production [15]. He substantiated the concept of the division of labor and also put forward "a number of the richest scientific achievements in the matter of... developing the correct methods of work, introducing the best accounting and control systems, etc." [15]. In the management hierarchy F.W. Taylor "singled out" functional specialists in accounting, staffing, sales and production of a company. The implementation of Taylor's concept in the applied aspect consisted in replacing the traditional linear control by a linear-functional structure. In the 1920 s the registration concept of controlling was originated. Controller's functions consisted in performing duties of managing financial investments, fixed capital and conducting audits [14]. The presence of the controller was due to the need to monitor the activities of company directors; the main purpose of the controller was to provide information about the real situation of a company to its owners.

The concept of accounting-oriented controlling was largely due to the economic crisis of the 1930s. The accounting-oriented concept takes place when information objectives are pursued, which are implemented, first of all, with the help of the accounting data. Such an approach can be characterized as profit-oriented or limited information-oriented, since the accounting data serve as the information base. Controlling uses relevant information based on the data in monetary terms and, as a result, it is related mostly to operational links. Therefore, controlling is primarily related to the operational level and only partly to the strategic level, when it comes to the potential for success [14]. In fact, the scientific publications, which focus on this concept of controlling, describe management accounting and provide methods and models of cost management and budgeting [16], [17].

Since the 1970s a number of concepts have been developed in Europe, each of which is a logical continuation of the previous one. A. Deyhle, R. Mann and E. Mayer were the representatives of the accounting-oriented concept. They associated the concept of controlling with profit management, a regulation system that allowed a company to obtain the maximum profit under the given conditions [18], [19].

In the 1970-1980s the information-oriented concept was formed, which coincided with the development of computer technology. The main function of controlling consisted in providing the company management with relevant information to plan, prepare and make decisions and to control. At the same time, the controllers had to regulate supply and demand of information by improving the electronic data processing and transmission systems. According to this concept, accounting remained an important source of information; however, quantitative and qualitative information obtained from various internal and external sources was also used. T. Reichmann was the representative of this concept. He considered the provision of the company management with information for decision-making as the main task of controlling. According to the words of P. Priceler, controlling is a management tool that goes beyond the limits of a single function; this tool supports internal company management and decision-making by means of targeted selecting and processing of information [20]. Consequently, at that time controlling was a function of management support, carried out by controllers. Controllers ensured that managers received necessary information throughout the management process. Nevertheless, these circumstances were a logical continuation of the natural development of management accounting. The definition of "controlling" was associated in this case with the notion of "management accounting" and did not present a new special area of management.

The coordination-oriented concept of controlling began its active development in the late 1980s-early 1990s and was based, first of all, on the divergence between the management system and the execution system. Accordance to this concept, the primary coordination of management decision-making was the task 
of the management system itself, and the secondary coordination within the management system was related to controlling. Within the given concept two directions of controlling were identified: 1) with emphasis on the planning, control and information management systems; 2) with emphasis on the company management system to achieve its objectives. The coordination function of controlling covered the formation and current execution of the processes of functions coordination.

P. Horvath defines controlling as a complex inter-functional management concept aimed at coordinating the systems of planning, control and information support [21]. Due to possible opportunistic behavior of managers or erroneous processing of information, management effectiveness may decrease. In order to avoid inefficient management the second direction of controlling with emphasis on the management system (in the context of the previous direction) is considered by some authors as a "management control system". During this period, based on the conclusions of his research, Professor Robert Kaplan and President of a consulting firm David Norton promoted the balanced scorecard system as one of the main tools of the coordination concept of controlling. The quintessence of the concept consisted in the following: if the strategic and operational indicators of the production and economic aspects of the company's activities are correctly selected, measured and balanced, then it will be possible to achieve the set goals and indicators in the future. The method of a balanced system of performance indicators connects the company's strategic installations and their implementation, thus, ensuring strategic development [22].

Since the 1990s the concept oriented towards strategic navigation has begun to form through the synthesis of the existing components of strategic management: strategic planning, information support and control. Controllers focus on setting and solving the tasks of information and analytical support for strategic management, since it is at this level that the future performance of an economic entity can be guaranteed. One of the main sources of information support in controlling is strategic accounting, which uses the method of strategic balances - external and internal ones as a tool (the experience of industrially developed countries of the West). At this historical stage controlling de facto ends the management cycle, the foundations (potentials) of the future efficiency of an economic entity are laid, the indicator systems are provided with information necessary for assessing strategic intentions and the degree of achieved strategic goals. In terms of strategic controlling the external and internal environment, competition, significant success factors, strategic plans and controlled performance indicators, value chains, strategic positioning, cost-accounting factors and a portfolio of strategies are analyzed. Thus, the controller becomes a "strategic" assistant (consultant) to the management in the course of forming strategic plans, solving problems of strategic accounting, control and analysis. However, presently, there is particular uncertainty in the approach to implementing this concept in the modern management theory.

The stakeholder concept began to be formed in the early 2000s within the corporate governance concept.

Corporate governance is understood as a system of interrelations, interactions and interconnections between company's managers and its owners to provide its efficiency and improved interests for all involved groups; it is aimed at gaining the maximum profit from all the company's activities in accordance with the current national legislation and taking into account the recognized international standards.

The stakeholder theory is associated with R.E. Freeman's work "Strategic Management: A Stakeholder Approach". R.E. Freeman defines a "stakeholder" as "any group or individual who can affect or is affected by the achievement of the organization's objectives" [23]. The stakeholder theory is inextricably linked to the management processes and their results arising from the resource relationship of a company with the stakeholders. Presently, basing on the provisions of a neo-institutional economy certain outlines of this concept are emerging, thus, making corporate structures both develop an optimal system of their own financial and economic parameters and take into account the interests of a wide range of stakeholders. From the standpoint of neo-institutionalism, the structure of the set of stakeholders is represented by a 
multitude of individuals who belong to different social institutions. This management structure does not depend on the interested entity and represents goals, resources and processes objectively. New goals, resources and processes are associated with the interest of an individual, and therefore can be represented only through communication with him. Corporate governance is the main internal mechanism, which is directly focused on resolving conflicts of institutional interests reflecting the main aspects of corporate culture as a subsystem of operational controlling.

According to the concept of controlling oriented towards optimizing the interests of stakeholders, there is a reduction in the costs of conflict between the interested parties (the state, owners, creditors, shareholders, personnel, competitors, social and environmental institutions, local community, etc.). The mentioned parties are represented by intra-corporate or external institutions that have their institutional relations, interests, norms and rules of behavior characteristic of national culture. In this regard, this concept should correspond to the priorities of economic innovative development at the present historical stage.

Currently, the concept of strategic navigation and the concept of optimizing the interests of stakeholders, which reflect the main aspects of corporate and national culture, are at the formative stage. Modern economic conditions create new prerequisites for further development of controlling as a subsystem of organizational economic management. At the same time, controlling should evolve in terms of increasing decentralization, self-organization, self-control, self-management, improving corporate culture that characterizes the value system of an economic entity.

\section{Conclusion}

Basing on the obtained results, a distinctive feature of the concept "controlling" was revealed: it reflects the versatility of the tools used in the system of organizational economic management of an economic entity, which is a complex system including various concepts that supplement each other.

The trajectory of the development of an economic entity depends on the whole spectrum of the controlling toolkit used in the system of organizational-economic management. Despite this fact, management currently does not involve such aspects as corporate culture and intellectual capital due to the erroneous belief that they are outside the system of organizational and economic management, which reduces the effectiveness of management decisions. To increase the effectiveness of management it is necessary to take into account the fact that organizational culture is not only an original combination of values, attitudes, norms, habits, traditions, behavior and rituals but also the entire habitat and self-realization of the organization, its inherent style of attitudes and behavior. In addition, each business entity has its own individual culture, which influences the economic development trajectory, and therefore, organizational culture in a market economy becomes a key factor in increasing efficiency of an economic entity.

At the present historical stage the organizational culture formation is under the constant influence of both internal and external factors. A purposeful change in the vector of organizational culture with regard to national cultural specifics can be achieved by means of intellectual capital in the system of organizationaleconomic management, which is based on the operational controlling toolkit. In this regard, the main aspects reflecting the essence of the concept "culture" are studied; the role of culture in the system of organizational-economic management of an economic entity is defined. Organizational culture is considered as a subsystem of operational control based on various models, one of which is the corporate culture model characterizing the value system of an economic entity, which provides the trajectory of effective economic development.

\section{Conflict of interest}

The authors confirm that the data do not contain any conflict of interest. 


\section{Footnotes}

1. Kovaleva, V.D. (2005). Financial controlling in business activities. Stavropol: Servisshkola.

2. Bobakho, V.A., Levikova, S.I. (2000). Cultural studies: A basic course program of, a textbook, a glossary. Moscow: FAIR-PRESS.

3. Anankina, E.A., Danilochkin, S.V., \& Danilochkina, N.G. (2002). Controlling as a management tool. Ed. by N.G. Danilochnina. Moscow: UNITY.

4. Tylor, E. B. (1871). Primitive culture. L: John. Murray.

5. Hofstede, G. J. (1991). Cultures and organizations. London: McGraw Hill Book Company.

6. Hofstede, G. J. (1993). Cultural constraints in management theories. The Academy of Management Executive, 7(1), 81-94.

7. Karminsky, A.M., Olenev, N.I., Primak, A.G., \& Falco, S.G. (2002). Controlling in business. Methodological and practical basics of controlling in organizations. Moscow: Finances and Statistics.

8. Deyhle, A. (1993). Beat Steigmeier und Autorenteam. Controller und Controlling. Bern, Stuttgart, Wien: Haupt.

9. Bruhl, R (2004). Controlling. Grundlagen des Erfolgscontrollings. Munchen: Oldenbourg Wissenshaftsverlag $\mathrm{GmbH}$.

10. Yung, H. (2003). Controlling. Munchen: Oldenbourg Wissenshaftsverlag GmbH.

11. Accounting Journal, 1895.

12. Falco, S.G. (2008). Controlling for managers and specialists. Moscow: Finances and Statistics.

13. Likhtarev, L.Yu. (2011). The systematization of definitions of "controlling". Economic Research, 2.

14. Khan, D. (1997). Planning and control: controlling concepts. Moscow: Finances and Statistics.

15. Tylor, F. (1991). The Principles of Scientific Management. Moscow: Controlling.

16. Sukhareva, L.A., \& Petrenko, S.N. (2002). Controlling - a basis of business management. Kiev: NikaCentre.

17. Popchenko, E.L., \& Ermasova, N.B. (2006). Business controlling. Moscow: Alpha-Press.

18. Deyhle, A. (2003). Controller-Praxis. Moscow: Finances and Statistics.

19. Mann, R., \& Mayer, E. (1992). Controlling for beginners: The system of profit management. Moscow: Finances and Statistics.

20. Reichmann, T. (1995). Controlling mit Kennzahlen und Managementberichten, Munchen: Vahlen ["Controlling" Based on Standards and Management Reports]. Berlin, pp. 23-25.

21. Horvath, P. (1996). Introduction to controlling. Munchen: Vahlen.

22. Norton, D., \& Kaplan, R. (2003). Putting balanced scorecard to work. Harvard Business Review, (September/October), pp. 134-147.

23. Freeman, R. E. (1984). Strategic management: A stakeholder approach. Boston. 


\section{References}

Anankina, E. A.; Danilochkin, S. V. \& Danilochkina, N. G. (2002). Controlling as a management tool. Ed. by N.G. Danilochnina. Moscow: UNITY.

Bobakho, V. A. \& Levikova, S. I. (2000). Cultural studies: A basic course program of, a textbook, a glossary. Moscow: FAIR-PRESS.

Bruhl, R. (2004). Controlling. Grundlagen des Erfolgscontrollings. Munchen: Oldenbourg Wissenshaftsverlag $\mathrm{GmbH}$.

Deyhle, A. (1993). Beat Steigmeier und Autorenteam. Controller und Controlling. Bern, Stuttgart, Wien: Haupt.

Deyhle, A. (2003). Controller-Praxis. Moscow: Finances and Statistics.

Falco, S. G. (2008). Controlling for managers and specialists. Moscow: Finances and Statistics.

Freeman, R. E. (1984). Strategic management: A stakeholder approach. Boston.

Hofstede, G. J. (1991). Cultures and organizations. London: McGraw Hill Book Company.

Hofstede, G. J. (1993). Cultural constraints in management theories. The Academy of Management Executive, 7(1), 81-94.

Horvath, P. (1996). Introduction to controlling. Munchen: Vahlen.

Karminsky, A. M.; Olenev, N. I.; Primak, A. G. \& Falco, S. G. (2002). Controlling in business. Methodological and practical basics of controlling in organizations. Moscow: Finances and Statistics.

Khan, D. (1997). Planning and control: controlling concepts. Moscow: Finances and Statistics.

Kovaleva, V. D. (2005). Financial controlling in business activities. Stavropol: Servisshkola.

Likhtarev, L. Yu. (2011). The systematization of definitions of "controlling". Economic Research, 2.

Mann, R. \& Mayer, E. (1992). Controlling for beginners: The system of profit management. Moscow: Finances and Statistics.

Norton, D. \& Kaplan, R. (2003). Putting balanced scorecard to work. Harvard Business Review, (September/October), pp. 134-147.

Popchenko, E. L. \& Ermasova, N. B. (2006). Business controlling. Moscow: Alpha-Press.

Reichmann, T. (1995). Controlling mit Kennzahlen und Managementberichten, Munchen: Vahlen ["Controlling" Based on Standards and Management Reports]. Berlin, pp. 23-25.

Sukhareva, L. A. \& Petrenko, S. N. (2002). Controlling - a basis of business management. Kiev: Nika-Centre.

Tylor, F. (1991). The Principles of Scientific Management. Moscow: Controlling.

Tylor, E. B. (1871). Primitive culture. L: John. Murray.

Yung, H. (2003). Controlling. Munchen: Oldenbourg Wissenshaftsverlag GmbH. 